\title{
Development Tin-Chromium Pillared in Bentonite as Catalyst for Ethanol to Gasoline Conversion
}

\author{
Robert Ronal Widjaya ${ }^{1,3}$, Ariadne Laksmidevi Juwono, ${ }^{2, *}$, and Nino Rinaldi ${ }^{3}$ \\ ${ }^{1}$ Departemen Fisika, Fakultas Matematika dan Ilmu Pengetahuan Alam, Universitas Indonesia \\ Kampus UI Depok 16424, Indonesia \\ ${ }^{2}$ Departemen Fisika, Fakultas Matematika dan Ilmu Pengetahuan Alam, Universitas Indonesia \\ Kampus UI Depok 16424, Indonesia \\ ${ }^{3}$ Research Center for Chemistry, Indonesian Institute of Sciences, Kawasan PUSPIPTEK Serpong, \\ Tangerang Selatan 15314, Indonesia \\ *Corresponding author's email: ariadne.laksmidevi [AT] ui.ac.id
}

\begin{abstract}
Bentonite is a natural material that can used as a buffer catalysts and easy to modified. Tin and Chromium metals can used as catalyst material. Tin and Chromium metals supported into bentonite was successfully prepared by pillarization method, and was calling Bi-Oxides pillared clays. It has used to catalyst for ethanol to gasoline conversion. Basal spacing for bentonite and $\mathrm{Sn}$-Cr/bentonite were 12,83Á and $25,67 A ́$ respectively. Specific surface area and pore volume of $\mathrm{Sn}$-Cr/bentonite was investigated and appeared be bigger than bentonite. The results confirmed by BET analysis that were $30,35 \mathrm{~m}^{2} / \mathrm{g}$ become $168,86 \mathrm{~m}^{2} / \mathrm{g}$ and pore volume from $0,0065 \mathrm{~cm}^{3} / \mathrm{g}$ become 0,03 $\mathrm{cm}^{3} / \mathrm{g}$. The thermal stability was determined by Thermogravimetry Analysis from temperature $0^{\circ} \mathrm{C}$ until $1000^{\circ} \mathrm{C}$ and the functional group changes detected by Fourier Transform Infra Red. XRF and EDX detected the Sn-Cr metals in the bentonite. The results of the liquid catalyst test analyzed by GC-MS and showed the contents consisted of benzene, toluene, octane, and naphthalene, that were similar with commercial gasoline. So, the Sn and Cr were using as metal pillars for bentonite interlayer and successfully used this Bi-oxides pillared clays for ethanol to gasoline conversion.
\end{abstract}

Keywords- Bi-Oxides, Pillared clays, Sn-Cr/Bentonite, Ethanol to Gasoline.

\section{INTRODUCTION}

Clay has a fine silica and fused aluminium. These elements, silicon, oxygen, and aluminium are the main elements of bentonite in the earth. Bentonite is one types of clay, that can used as catalyst support materials. Bentonite has two layers of tetrahedral compiled of Silicon oxide and sandwiches one layer octahedral compiled of Aluminium oxide. There is a space that can expanded in the interlayer bentonite. Furthermore, loaded with water particles and different cations that can exchanged ${ }^{[1-2]}$. Pillared clays are a cation exchange process by heating process of a metal solution and the bentonite forms an oxide structure such as a pillar supporting the phillosilicate sheets in the interlayer bentonite. The latest research about pillared clays has developed in adsorption and catalytic reaction, because bentonite is relatively easy to modified by using metal pillars such as titanium, ferrum, aluminium, and others depending on the usage ${ }^{[3-6]}$. Bentonite is easy to obtained, cheap, and easy to prepared as catalyst support. The change of two metal alloys can also control or form a size according to apply of the catalyst material, since sometimes large pore dimensional structures are poorly adapted to adsorbed small-dimensional impurities ${ }^{[7]}$.

Pillarization is a process of cation exchange contained in natural clay with polycation contained in a metal solution used as a pillar, then heating process to form an oxide structure such as a pillar supporting the phillosilicate sheets one from the other. The clay which was polarized by the metal material as its buffer has the ability to increase the catalytic power and acid-base properties that can applied to aid the catalytic processes, such as conversion of ethanol to gasoline, but not to damage react from the conversion process of ethanol to gasoline. has a chemical content equal to commercial fuel.

The basal spacing is the distance between the layers of alumina-silicate has water molecule and ions that can exchanged with pillar metals ${ }^{[8]}$. This $\mathrm{Sn}$ and $\mathrm{Cr}$ banded in the alumina-silica layers of bentonite and it made basal spacing becomes larger. $\mathrm{Sn}$ and $\mathrm{Cr}$ could be increased basal spacing in the alumina-silicate layers in bentonite, to allow a greater basal spacing. In this research, catalyst material properties required that has the larger of basal spacing. The 
enhancement of basal spacing, also indicated by increasing the specific surface area and pore volume of bentonite. From the previous research, tin pillared clays were used as adsorbents for hazardous wastes and other studies have done the ethanol to gasoline (ETG) conversion process by zeolite catalysts. The ETG conversion used Sn-Cr/bentonite has not been done, therefore in this research $\mathrm{Sn}-\mathrm{Cr}$ /bentonite catalyst was used for ETG conversion.

Tin oxide-Pillared Clays (Tin PILCs) can also be used as adsorbents for adsorption reactions in the pharmaceutical field for absorbing trimethoprim and sulfamethoxazole in wastewater from the pharmaceutical industry. Tin PILCs have a large pore character and also a large pore volume and evenly on the surface of organoclay so that Tin PILCs able to become adsorbent ${ }^{[9-10]}$. Chromium compounds are strong oxides at low-pH, so chromium has a fairly good acidity as an acid catalyst. Chromium can also be carcinogenic in industrial waste, and usually to absorb chromium in industrial waste by using bentonite ${ }^{[11]}$.

Pillared bentonite comparable to zeolite that could used for ETG conversion and reported to have large pores and spesific surface area ${ }^{[12]}$. Gasoline is a liquid oil fraction with a boiling point between $30-200^{\circ} \mathrm{C}$, consisting of a mixture of hydrocarbons between $\mathrm{C}_{4}$ and $\mathrm{C}_{12}{ }^{[13]}$. The most important compounds in gasoline is Benzene which has the chemical formula of $\mathrm{C}_{6} \mathrm{H}_{6}$. Which is an organic chemical compound that is colorless, flammable, and has a distinctive aroma. Benzene has a high octane number, it is one of the components in petroleum. Consolidated Bronsted and Lewis acids are indispensable in the process of making these catalysts, because Bronsted acid has ability to give electrons, while Lewis acid has a lot of blank cavity capable of receiving electron pairs.

The process of ETG is one of the precise processes in producing gasoline as a vehicle engine fuel, because this process does not produce harmful residues that can damage the environment. In addition, the results of the production process also produces environmentally friendly fuel, from renewable raw materials. The novelty of this research is to produce $\mathrm{Sn}-\mathrm{Cr} / \mathrm{Bentonite}$ as catalyst and be used to ETG conversion.

\section{EXPERIMENTAL PROCEDURE}

\subsection{Preparation of Materials}

Commercial bentonite was acquired from Sigma Aldrich (285234), Chromium (III)-Cloride hexahydrate/ $\mathrm{Cl}_{3} \mathrm{Cr} .6 \mathrm{H}_{2} \mathrm{O}$ was from Merck (1.02487.1000), and Tin(IV) Cloride was from Merck (1.07810.0500). Sn-Cr/bentonite was synthesised by a pillarization method. The solution concentrations of the $\mathrm{Cl}_{3} \mathrm{Cr}, \mathrm{SnCl}_{4}$, and $\mathrm{NaOH}$ for blend were $0.2 \mathrm{M}$. $\mathrm{NaOH}$ solution was trickled gradually into the $\mathrm{Sn}-\mathrm{Cr}$ solvent under steady mixing for $24 \mathrm{~h}$. Separately, some amount of bentonite were mixed in $500 \mathrm{~mL}$ refined water at $65^{\circ} \mathrm{C}$ for $2 \mathrm{~h}$. The $\mathrm{Sn}-\mathrm{Cr}$ metal pillars was poured to the bentonite suspension under steady blending for $12 \mathrm{~h}$. The ingredient was strained, and washed with refined water, then dried in the oven at $100^{\circ} \mathrm{C}$ for $24 \mathrm{~h}$.

\subsection{Characterization Method}

Characterization by X-Ray Diffraction measurement were conducted use $\mathrm{Cu}-\mathrm{K} \alpha$, with a step size of $0,01 \mathrm{deg}$, scanning speed of $2 \mathrm{deg} / \mathrm{min}$, and $\lambda=1.54 \AA$, and a step width of $0.01 \mathrm{deg}$. Thermogravimetry investigation by Q50 V20 software with a powder material was heated up to the operating temperature of $1000^{\circ} \mathrm{C}$ in a platinum pan. The balance gas of thermogravimetry was nitrogen $40 \mathrm{ml} / \mathrm{min}$ and flow rate of oksigen $60 \mathrm{ml} / \mathrm{min}$, with a heating rate of $10^{\circ} \mathrm{C} / \mathrm{min}$ up to $950^{\circ} \mathrm{C}$. $\mathrm{KBr}$ phase method was applied for Fourier Transform Infra-Red by Shimadzu analysis and prestige- 21 with ATR 4000 software added to an automatic data acquisition center. Measurement by X-Ray Fluorescence, model Niton Thermo Fisher Scientific and type XL3t was conducted in duration time 90-100s by a soil mode technique. Analysis of Brunauer Emmett Teller by Micromeritics Tristar II software with N2 gas analysis absorptive and equilibration interval $10 \mathrm{~s}$ for analysis of the sample mass $0.35 \mathrm{~g}$, sample condition cold free space $32.81 \mathrm{~cm}^{3}$, density of sample material 1 $\mathrm{g} / \mathrm{cm}^{3}$, and Barret-Joyner-Halenda $(\mathrm{BJH})$ technique. The micro observation was carried out by Scanning Electron Microscopy/Energy Dispersive X-Ray Analysis (Hitachi SU-3500), operated at 20kV. Gas Chromatography-Mass Spectrometry was conducted at a set point temperature of $40-325^{\circ} \mathrm{C}$, heating rate of $10^{\circ} \mathrm{C} /$ minute in a normal scanning.

\section{RESULTS AND DISCUSSION}

XRD patterns of Bentonite and $\mathrm{Sn}-\mathrm{Cr} /$ bentonite can seen in Figure 1. It shows that the basal spacing $\left(\mathrm{d}_{001}\right)$ of bentonite, which is related to the peak at $2 \theta=7,32^{\circ}$ is $12,83 \AA$. There are two peaks at $2 \theta=3,46^{\circ}$ and $5,83^{\circ}$ corresponding to $\mathrm{d}_{001}=25,67 \AA$ and $\mathrm{d}_{002}=15,10 \AA$. Respectively these two peaks show the exist of Sn metal at $2 \theta=7,32^{\circ}$ and $\mathrm{Cr}$ metal at $2 \theta=5,83^{\circ}$. This result goes well with previous result ${ }^{[14]}$. It means there was a reaction interaction one edge of crystal clay with $\mathrm{Sn}-\mathrm{Cr}$ metal cations, and attract into alumina-silicate layers in the bentonite. The presence of $\mathrm{H}^{+}$cations derived from the acid between the bentonite interlayer replacing the alumina-silicate layers as balancing cations in bentonite causes the expand of the basal spacing in bentonite ${ }^{[15]}$. Basically alkaline bentonite, activation process or treatment with 
acid can reduce the contain of alkaline and alkaline earth oxides such as $\mathrm{Na}_{2} \mathrm{O}, \mathrm{K}_{2} \mathrm{O}, \mathrm{MgO}$, and $\mathrm{CaO}$ due to substitution of $\mathrm{H}^{+}$ion, resulting in the increase of $\mathrm{H}^{+}$site (Bronsted acid ). The activation process with acids performed on bentonite at the certain metal ratio concentration also resulted in the dissolve of aluminum (dealumination) which eventually resulted in the Lewis acid site $\mathrm{Al}^{3+}{ }^{[16]}$.

Figures 2 (a) and (b) show the results of TGA measurement. Decomposition processes that cause reduce the weight of the material with heating range from temperature $100^{\circ} \mathrm{C}$ up to $750^{\circ} \mathrm{C}$. Fig. 2(b) shows that $\mathrm{Sn}-\mathrm{Cr} / \mathrm{bentonite}$ has three stages of weight reduction. In the first phase there was a weight reduction of $10.09 \%$. This weight reduction was due to the release of water molecular groups in bentonite interlayers on the physical surface. The second phase of weight reduction of $3.45 \%$ in the temperature range of $250-550^{\circ} \mathrm{C}$ occured by eliminate water molecules due to the condensation of the hydroxyl structure and also the dehydroxylation process in the $\mathrm{Sn}-\mathrm{Cr}$ oxide among the alumina-silicate layers. While in the third stage, there is a weight reduction of $2.15 \%$ in the temperature range of $550-750^{\circ} \mathrm{C}$, which related to followed by the loss of water molecules on the pillar structure of $\mathrm{Sn}$ and $\mathrm{Cr}$ metal collapsing the bentonite structure. This results was in accordance with M.E. Gyftopoulou et al. ${ }^{[17]}$.

The FTIR analysis is shown in Figure 3. Bentonite has five spesific peaks. On the wave number of $1032 \mathrm{~cm}^{-1}$ is $\mathrm{Si}-\mathrm{O}$ and wave number $3632 \mathrm{~cm}^{-1}$ is Al-O and Al-O-Si change is a layer of structure in bentonite has been influenced by the process of pillarization. Wave numbers of $698 \mathrm{~cm}^{-1}, 1041 \mathrm{~cm}^{-1}$ and $1090 \mathrm{~cm}^{-1}$ related bending vibration $\mathrm{Mg}-\mathrm{OH}, \mathrm{Si}-\mathrm{O}-\mathrm{Si}$ stretching vibration and $\mathrm{Si}-\mathrm{O}-\mathrm{Si}$ stretching bands (longitudinal mode) in tetrahedral or $\mathrm{SiO}_{2}(\mathrm{Quartz})$ layers. There is a $\mathrm{Si}$ $\mathrm{O}$ group indicated by the presence of sharp and high intensity absorption bands at $1041 \mathrm{~cm}^{-1}$ to $780 \mathrm{~cm}^{-1}$ wave numbers indicating exist asymmetric stretching of Si-O. The high intensity of the absorption peak at $1041 \mathrm{~cm}^{-1}$ for $\mathrm{Sn} / \mathrm{bentonite}$ shows the high content of montmorillonite minerals in bentonite. Bentonite contains hydroxyl compound, it can also be seen from the TGA result at high temperature. The hydroxyl compounds were released as a result of the deformation of the compiler, bentonite structure. Exist of the other IR spectra indicates added element or compound of metal pillars that has been added in bentonite interlayers, which the metal pillars are arranged and bonded stronger.

The wave number are $3624 \mathrm{~cm}^{-1}$ shows vibration of the $-\mathrm{OH}$ group, the hydroxyl group attached to Al-coated octahedral Al-Al-OH on bentonite and -OH stretching of the hydroxyl structure. Then at the wave number of $3456 \mathrm{~cm}^{-1}$ related to $-\mathrm{OH}$ stretching and $-\mathrm{OH}$ deformation of water molecules adsorbed in bentonite. This reinforces the absorption band of the $1641 \mathrm{~cm}^{-1}$ wave number indicating the vibration of $\mathrm{H}-\mathrm{O}-\mathrm{H}$ from the adsorbed water in bentonite. Sn$\mathrm{Cr} /$ bentonite which was a balance side of Bronsted and Lewis acid, added Sn and Cr metal greatly affect the properties of this catalyst material, given acidity of the catalyst material has an important role for a chemical reaction process to be catalyzed. It probably indicated that the combine of two metal oxides as a catalyst could improve the properties of the catalyst material compared with single metal oxide, but it is also indicated by the shift of wave numbers between bentonite and pillared bentonite with $\mathrm{Sn}, \mathrm{Cr}$, and joined $\mathrm{Sn}-\mathrm{Cr}$ metals. These results went well with previous research ${ }^{[18]}$.

Table 1 lists the XRF analysis. It can be seen that the bentonit contains all the elements mentioned in the table except $\mathrm{Sn}$. Basically the impurity elements ( $\mathrm{Sr}$ and $\mathrm{Mn}$ ) are not very influential when the catalyst material is used for the conversion process, because the content is very small (below $0.5 \%$ ). While the most important element, namely elements $\mathrm{Sn}$ and $\mathrm{Cr}$ which buffer the main elements alumina-silicate in bentonite.

Specific surface area and pore volume of $\mathrm{Sn}-\mathrm{Cr} /$ bentonite significantly increased compared to bentonite. This is exhibited to Figures 4(a) and (b). It is indicated that $\mathrm{Sn}-\mathrm{Cr} /$ bentonite has excellent specific surface area material and volume of pore material for catalysis process, as catalyst material is required large specific surface area characters and large pore volume. The larger specific surface area material and more pore volume, then more places to do the catalysis reaction ${ }^{[19]}$. It influenced of polication dimensions of $\mathrm{Sn}$ and $\mathrm{Cr}$ metal bond to the bentonite interlayer, so that enlarged the basal spacing as confirmed by XRD measurements ${ }^{[20]}$. In the bentonite interlayer, there are ions that can intercalated, which is the position of the ions are spread, when already pillarization process with $\mathrm{Sn}$ and $\mathrm{Cr}$, ions in bentonite interlayer will be replaced with metal $\mathrm{Sn}$ and $\mathrm{Cr}$-oxide become shipshape position or elongated, so that the aluminasilicate coating on bentonite will also be lifted wider. Thus the greater the basal spacing, can be correlated with the increase of specific surface area and pore volume on pillared bentonite.

Figure 5 shows $\mathrm{Sn}-\mathrm{Cr} /$ bentonite had different grains with bentonite. The results of EDX measurements as located in Tabel 2, confirmed the XRF measurements which showed that there is $\mathrm{Cr}$ content of element in $\mathrm{Sn}-\mathrm{Cr} / \mathrm{bentonite}$. Similarly, from the measurements with XRD showing a new peak that is different from the peak position of $\mathrm{Sn} / \mathrm{bentonit}$. The difference between the particles of bentonite and the pillared bentonite. $\mathrm{Sn}-\mathrm{Cr} /$ bentonite was formed more particles, either in the form of granules with size $9 \pm 4 \mu \mathrm{m}$ such as SEM results in Sn/bentonit material or flake with size $22 \pm 6 \mu \mathrm{m}$ as the result on $\mathrm{Cr}$ /bentonit. It is desirable in this research, because with the formation of the particles, the catalyst material has much larger specific surface area and pore volume, that confirmed result of BET measurements, so with much particles, then more space for chemical reaction to the catalyst. 
XRF measurements of bentonite and $\mathrm{Sn}-\mathrm{Cr}$ /bentonite can correlated with SEM/EDX measurements, where $\mathrm{Sn}-\mathrm{Cr}$ content in pillared bentonite has sufficiently dominant $\mathrm{Sn}$ content, which corresponds to the number of atoms on the surface as well bentonite interlayer, which also causes the basal spacing between layers of alumina-silicate be greater and the strength of the crystal structure confirmed by XRD measurement data. This crystal structure corresponds to the number of electrons contained at a particular point in bentonite and it can seen at the intensity of XRD. It also affects the specific surface area of clay material and pore volume on the BET measurement results, so it can indicate that with the additional of Sn pillar metal in bentonite, the specific surface area of clay material and pore volume also increase ${ }^{[21]}$.

Table 2 lists the EDX analysis of $\mathrm{Sn}-\mathrm{Cr} /$ bentonite at 6 spots as exhibited in Figure 6. Oxygen always dominates in all spot, because the compounds in both bentonite and $\mathrm{Sn}-\mathrm{Cr}$ /bentonite are oxide compounds, such as $\mathrm{SiO}_{2}, \mathrm{Al}_{2} \mathrm{O}_{3}, \mathrm{Fe}_{2} \mathrm{O}_{3}$, $\mathrm{MgO}, \mathrm{CaO}$ was addition of $\mathrm{Sn}$ and $\mathrm{Cr}$ element indicated that the pillarization of two metal $\mathrm{Sn}$ and $\mathrm{Cr}$ in bentonite was success. $\mathrm{Na}, \mathrm{K}$, and $\mathrm{Ca}$ elements disappeared, because the content is very small, so that the remaining are the main elements contained in bentonite that have strong bonds. With such a strong catalyst bond it able to withstand at high temperatures when a catalytic test is conducted to react the ethanol to gasoline. The metals contained in Table 2 are indispensable to these catalysts, since they are attached to hydrocarbon compounds and have acid properties or become substances that can give protons $\left(\mathrm{H}^{+}\right.$ions) to other substances capable of receiving free electron pairs from an alkaline substance. In the case of ethanol, the carbon chain in ethanol was be engineered to be longer and becomes new compounds with properties similar to gasoline.

Table 3 shows the GCMS comparison between commercial gasoline with converted gasoline that was obtained by $\mathrm{Sn}-\mathrm{Cr} /$ bentonite catalyst. Commercial gasoline sample is used as a reference to compare the ethanol conversion results after the catalysis test process. The chemical formula of ethanol is $\mathrm{C}_{2} \mathrm{H}_{5} \mathrm{OH}$ which will be through dehydration, cracking and oligomerization process, causing the carbon chain to be disconnected and connected which extend the carbon chain becomes $\mathrm{C}_{4}$ or more. ETG conversion by $\mathrm{Sn}-\mathrm{Cr} /$ bentonite catalysts resulted in some of the major compounds contained in gasoline and visible differences in nominal percentages of areas in the Table 3. Sn-Cr/bentonite converted ethanol and produced gasoline similar to commercial gasoline specification. The highest content of o-xylene, $\mathrm{p}$-xylene, toluene, and benzene $\left(\mathrm{C}_{6}\right)$ are contain of octane $\left(\mathrm{C}_{8}\right)$, as well as aromatic hydrocarbon compounds such as naphthalene $\left(\mathrm{C}_{10}\right)$, then from some of the catalysis process it can seen that the cracking process and oligomerization has occurred, because ethanol which is class $\mathrm{C}_{2}$ can be converted into classes $\mathrm{C}_{4}, \mathrm{C}_{6}, \mathrm{C}_{8}$ and $\mathrm{C}_{10}$ with the following reaction mechanisms ${ }^{\text {[22] }}$.

$$
\begin{gathered}
\mathrm{C}_{2} \mathrm{H}_{5} \mathrm{OH}+\mathrm{C}_{2} \mathrm{H}_{5} \mathrm{OH} \rightarrow n-\mathrm{C}_{4} \mathrm{H}_{9} \mathrm{OH}+\mathrm{H}_{2} \mathrm{O} \\
\mathrm{C}_{2} \mathrm{H}_{5} \mathrm{OH}+1-\mathrm{C}_{4} \mathrm{H}_{9} \mathrm{OH} \rightarrow 1-\mathrm{C}_{4} \mathrm{H}_{9} \mathrm{OH}+\mathrm{H}_{2} \mathrm{O} \\
\mathrm{C}_{2} \mathrm{H}_{5} \mathrm{OH}+1-\mathrm{C}_{6} \mathrm{H}_{13} \mathrm{OH} \rightarrow 1-\mathrm{C}_{8} \mathrm{H}_{17} \mathrm{OH}+\mathrm{H}_{2} \mathrm{O} \\
1-\mathrm{C}_{8} \mathrm{H}_{17} \mathrm{OH}+\mathrm{H}_{2} \mathrm{O}+\mathrm{C}_{2} \mathrm{H}_{5} \mathrm{OH} \rightarrow \mathrm{C}_{10} \text { alcohols }+\mathrm{H}_{2} \mathrm{O}
\end{gathered}
$$

$\mathrm{Sn}$ and $\mathrm{Cr}$ metal in bentonite became as a catalyst in the reaction. The content of $\mathrm{H}^{+}$cations in the pillared bentonite cut off the $-\mathrm{OH}$ bond on ethanol, when the $-\mathrm{OH}$ bond is disconnected or suspended, the carbon content present in ethanol bound to another carbon and formed a new longer carbon chain. While the $-\mathrm{OH}$ disconnecting will bind with hydrogen and formed $\mathrm{H}_{2} \mathrm{O}$. The chemical reactions occurred in the pores of bentonite and also on the surface of the catalyst material. In correlation with BET analysis results are the specific surface area of clay material and pore volume that is larger, so that ethanol will be easily enter into bentonite to react and with larger specific surface area, more ethanol converted. Sn-Cr/bentonite have unique structures and react ethanol into compounds that are similar to commercial fuels. With these considerations, it is expected that the results of this process produce techno-economically competitive fuel engines or can also be used as additives to increase the octane rating of the engine fuel.

Based upon the outcome of XRD measurement, it could be that the process $\mathrm{Sn}-\mathrm{Cr}$ pillarization in interlayer of raw bentonite were successfully carried out. Both the bentonites were damaged by three steps (1) the loss of water molecules, (2) dehydration process, and (3) dehydroxylation process (release of the -OH bond) on the metal oxides contained in the bentonite structure in the range temperature. The arrangement of the pillar metal forming a layer of the paraffin layer coated on the alumina-silicate layer makes the metal pillars bonded stronger, since the metal pillars are arranged regularly compared to the ions in bentonite without pillars. The presence of a hydroxyl compound bond can strengthen the metal bonding of the pillars as well, so when subjected to heating at high temperatures, the metal pillars are not rapidly degraded. This is seen with the increase in temperature, the weight of the bentonite material is reduced by a relatively small value, because the metal pillars also do not collapse directly. The pillared bentonite has considerable metal content between the interlayer, so the water molecule is weak and easily released by the first heat treatment, while for the last stage, the pillared bentonite be through a relatively smaller weight reduction compared to bentonite without pillars, because the pillared bentonite has been the metal bonded to the interlayer affects the crystallinity of bentonite, so having a more stable character and better heat resistance. 


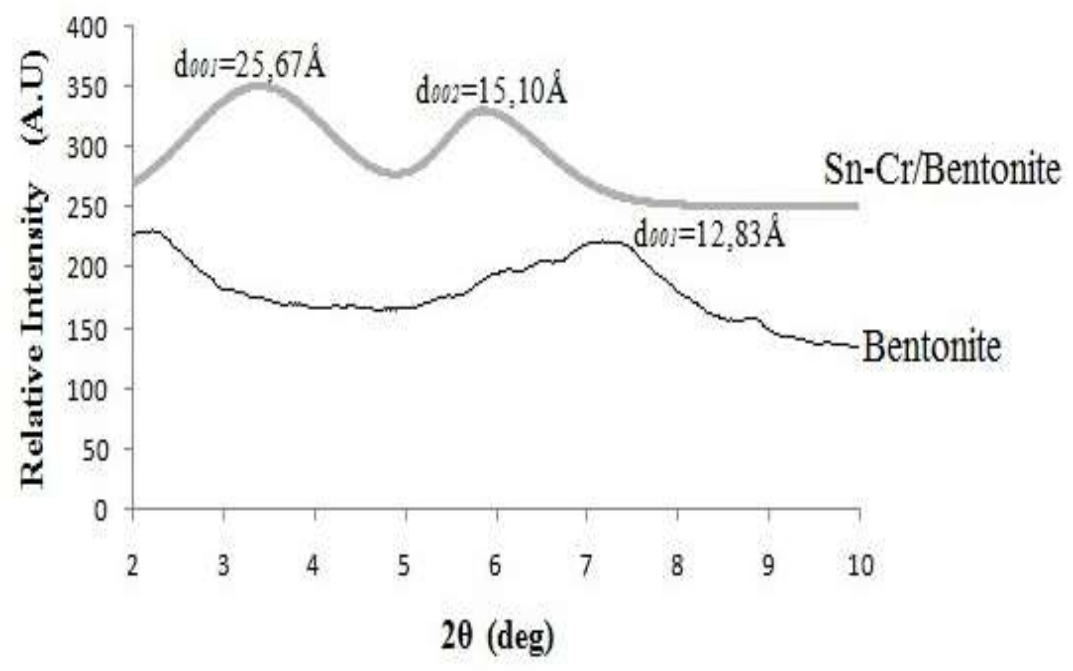

Figure 1: Results of XRD analysis patterns of raw bentonite and $\mathrm{Sn}-\mathrm{Cr} / \mathrm{bentonite}$

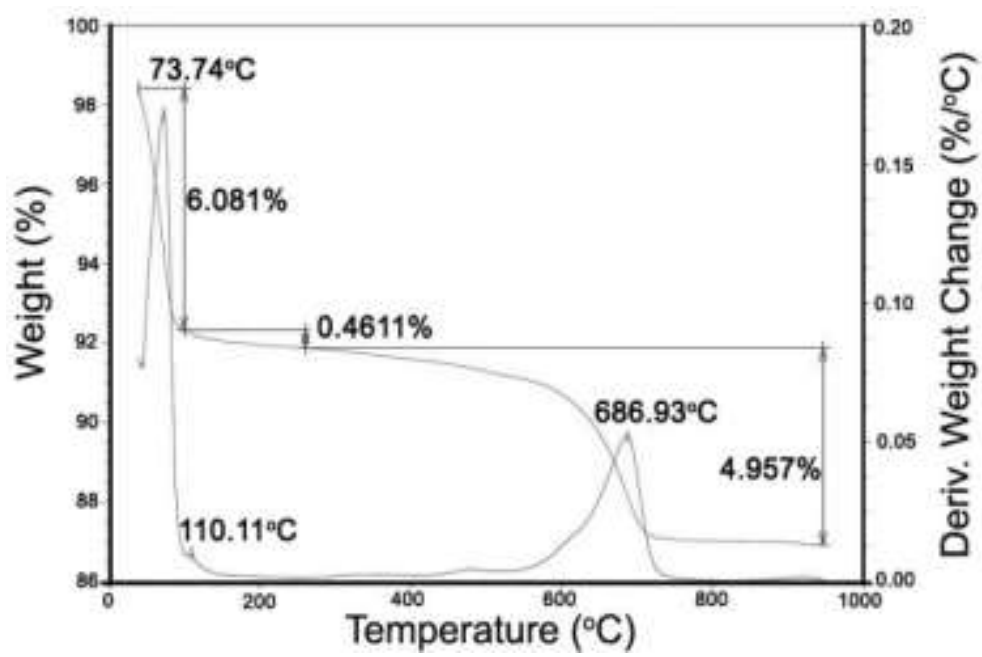

(a)

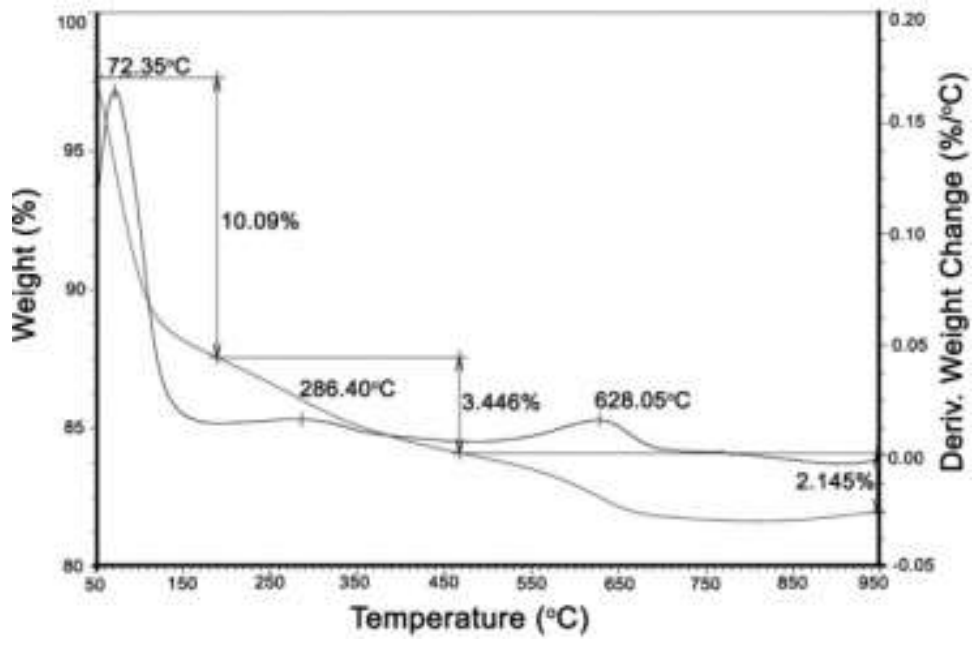

(b)

Figure 2: (a) Results of TG analysis curves raw bentonite, (b) $\mathrm{Sn}-\mathrm{Cr} /$ bentonite 


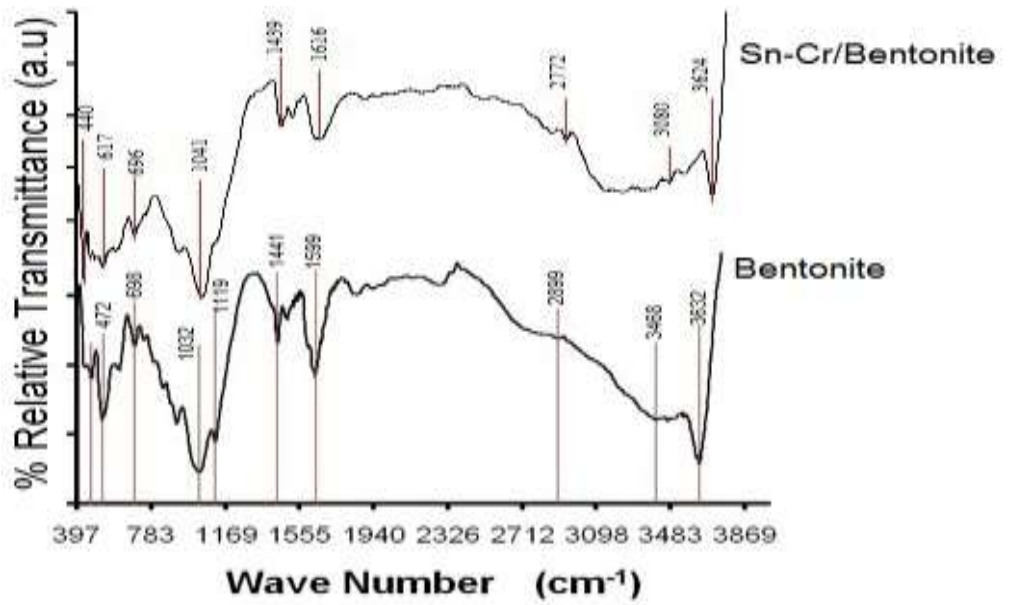

Figure 3: Results of FTIR

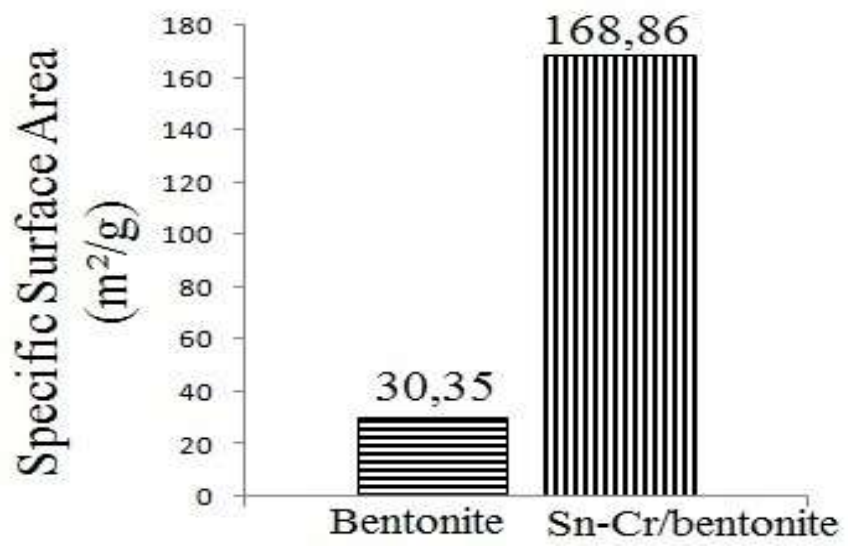

(a)

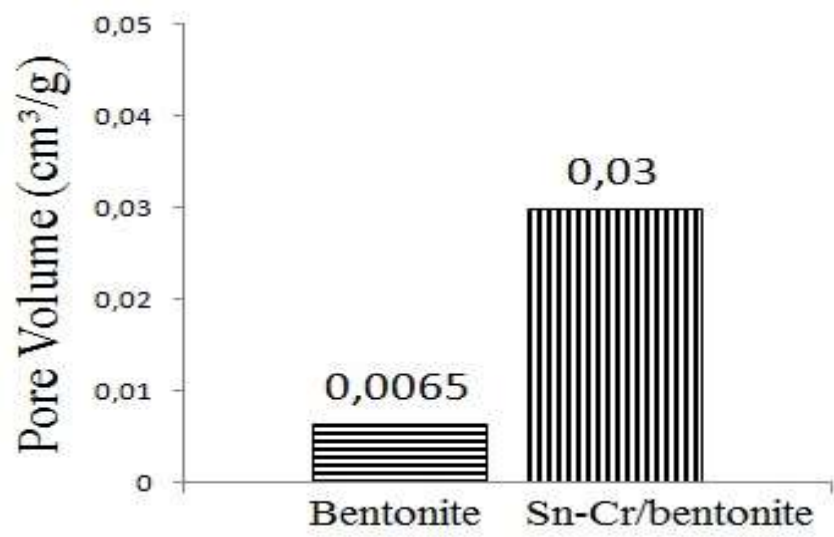

(b)

Figure 4: (a) Spesific Surface Area Material, (b) Volume of Pore Material 


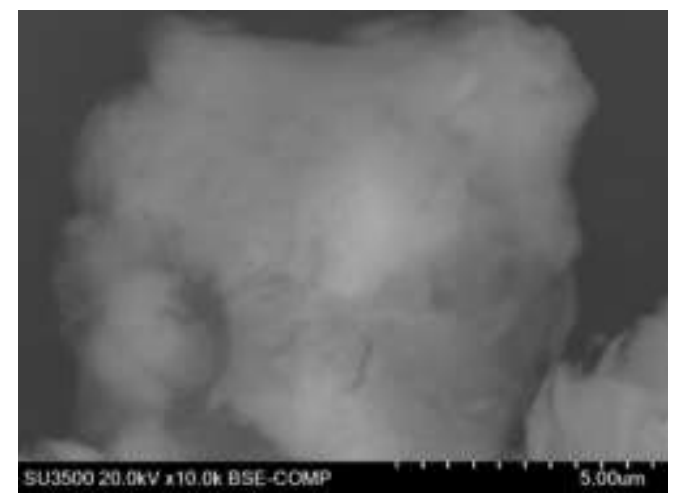

(a)

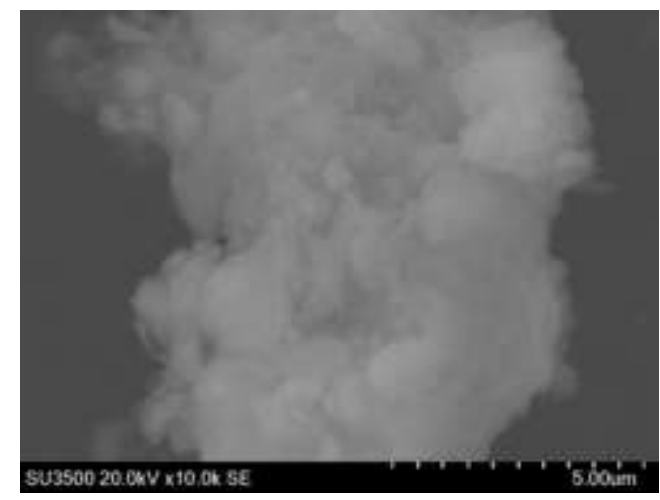

(b)

Figure 5: SEM image of (a) Bentonite, (b) Sn-Cr/bentonite
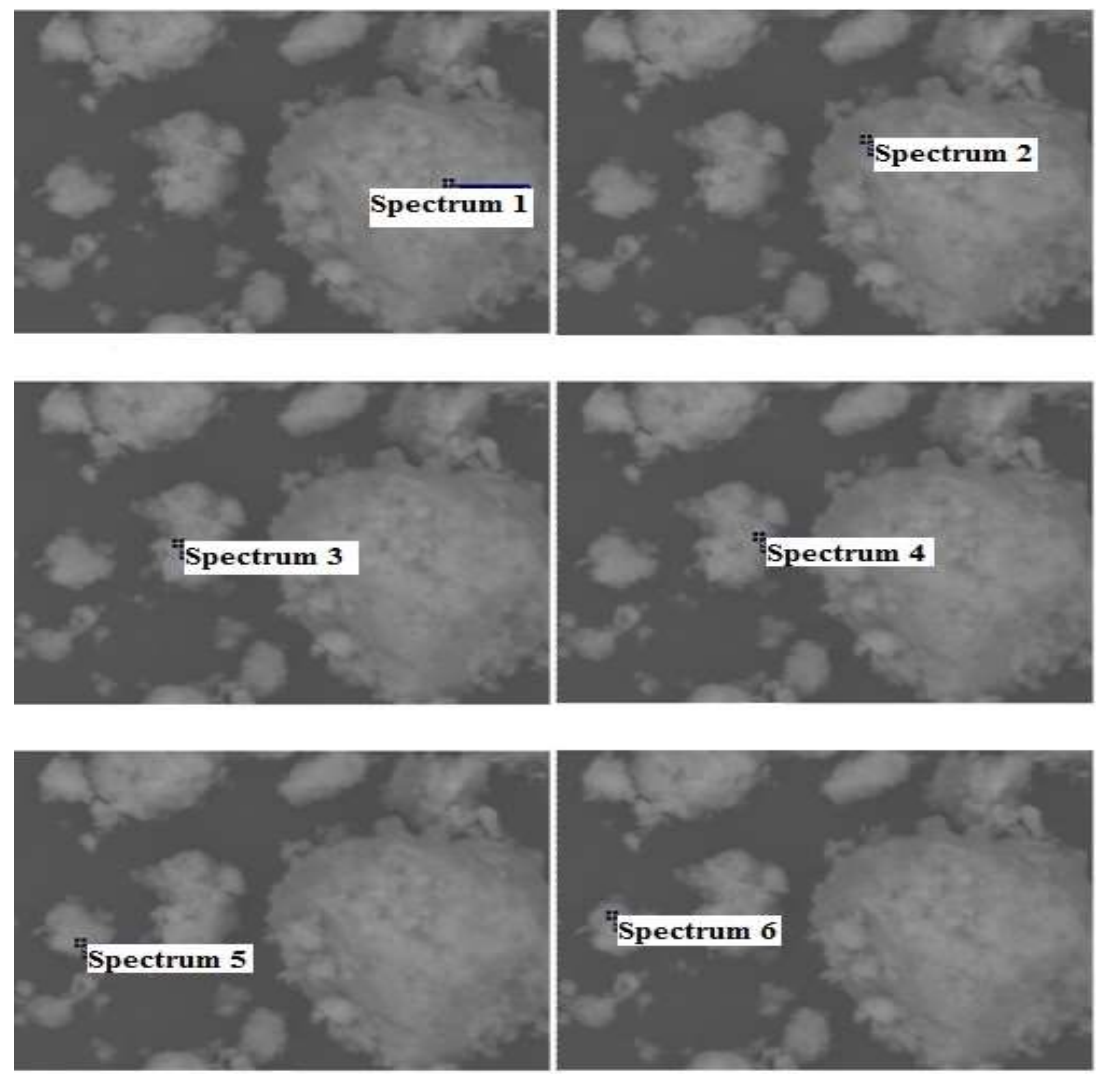

Figure 6: SEM/EDX image of $\mathrm{Sn}-\mathrm{Cr} /$ bentonite

Table 1: Results of XRF analysis (in content \%)

\begin{tabular}{|c|c|c|c|c|c|c|c|c|c|c|c|c|}
\hline Analyse & Mo & Zr & Sr & Fe & Mn & Cr & Sn & Cd & Ag & Pd & Si & Al \\
\hline Bentonit & 0,017 & 0,052 & 0,048 & 10,060 & 0,088 & 0,062 & - & 0,216 & 0,278 & 0,155 & 12,360 & 4,230 \\
Sn-Cr & 0,002 & 0,011 & - & 1,548 & - & 1,254 & 43,232 & 0,161 & 0,166 & 0,047 & 10,760 & 4,800 \\
\hline
\end{tabular}


Table 2: EDX analysis of $\mathrm{Sn}-\mathrm{Cr} /$ bentonite (in weight \%)

\begin{tabular}{|c|c|c|c|c|c|c|}
\hline Element & Spectrum 1 & Spectrum 2 & Spectrum 3 & Spectrum 4 & Spectrum 5 & Spectrum 6 \\
\hline $\mathrm{C}$ & 6.76 & 19.76 & 17.46 & 27.71 & 32.15 & 33.76 \\
$\mathrm{O}$ & 49.82 & 51.07 & 50.72 & 41.17 & 43.77 & 45.18 \\
$\mathrm{Mg}$ & 0.59 & 0.45 & 0.52 & 0.39 & 0.35 & 0.33 \\
$\mathrm{Al}$ & 4.50 & 3.26 & 3.62 & 3.28 & 2.99 & 3.31 \\
$\mathrm{Si}$ & 11.56 & 8.10 & 8.97 & 8.40 & 7.17 & 7.36 \\
$\mathrm{Cr}$ & 1.00 & 0.72 & 0.78 & 0.80 & 0.65 & 0.52 \\
$\mathrm{Fe}$ & 0.90 & 0.65 & 0.67 & 0.70 & 0.64 & 0.59 \\
$\mathrm{Sn}$ & 24.86 & 16.00 & 17.25 & 17.54 & 12.28 & 8.94 \\
\hline
\end{tabular}

Table 3: Results of GCMS test for Commercial Gasoline and Converted Gasoline by Sn-Cr/Bentonite Catalyst

\begin{tabular}{|c|c|c|c|}
\hline \multicolumn{2}{|c|}{ Commercial Gasoline } & \multicolumn{2}{|c|}{ Converted Gasoline } \\
\hline Library/ID & Area $(\%)$ & Library/ID & Area $(\%)$ \\
\hline Sec-Butyl acetate & 2,48 & Sec-Butyl acetate & - \\
\hline Toluene & 14,59 & Toluene & 12,08 \\
\hline Octane & 1,03 & Octane & 1,89 \\
\hline Ethylbenzene & 4,14 & Ethylbenzene & 3,78 \\
\hline o-Xylene, p-Xylene & 20,94 & o-Xylene, p-Xylene & 22,49 \\
\hline Benzene, 1,3-dimethyl & 6,4 & Benzene, 1,3-dimethyl & 7,24 \\
\hline Benzene, 1-ethyl-4-methyl & 11,3 & Benzene, 1-ethyl-4-methyl & 5,57 \\
\hline Benzene, 1,2,3-trimethyl & 10,08 & Benzene, 1,2,3-trimethyl & 10,74 \\
\hline Mesitylene & 3,28 & Mesitylene & 8,05 \\
\hline Benzene, 1-ethyl-2,3-dimethyl & 2,93 & Benzene, 1-ethyl-2,3-dimethyl & 3,04 \\
\hline Benzene, 1,4-diethyl & 0,41 & Benzene, 1,4-diethyl & 3,47 \\
\hline Benzene, 1-ethyl-3,5-dimethyl & 8,44 & Benzene, 1-ethyl-3,5-dimethyl & 3,83 \\
\hline Naphthalene & 2,43 & Naphthalene & 4,66 \\
\hline Naphthalene, 1-methyl & 1,12 & Naphthalene, 1-methyl & 4,5 \\
\hline Naphthalene, 2-methyl & 1,61 & Naphthalene, 2-methyl & 1,65 \\
\hline $\begin{array}{l}\text { Nitrous oxide,Piperazine, } 1 \text { - } \\
\text { methyl }\end{array}$ & - & $\begin{array}{l}\text { Nitrous oxide, Piperazine, 1- } \\
\text { methyl }\end{array}$ & 7,01 \\
\hline
\end{tabular}




\section{CONCLUSION}

Bentonite was successfully pillared by $\mathrm{Sn}-\mathrm{Cr} /$ Bentonite as the basal spacing increased from $12,83 \AA$ to $25,67 \AA$. TGA results shows the ability of catalysts at high temperatures and also the process of material decomposition along with released water molecules and hydroxyl compounds contained in the temperature $550^{\circ} \mathrm{C}$ and $750^{\circ} \mathrm{C}$ respectively. Results of FTIR show functional group bonds and differences between bentonite and pillared bentonite, as well as known Bronsted on wave number $1616 \mathrm{~m}^{-1}$ and Lewis acid types on $1439 \mathrm{~m}^{-1}$. Measurements with XRF and EDX result in the content of elements in bentonite, to know the additional of Sn-Cr metals in pillared bentonite. Measurements with BET indicate increased specific surface area from $30,35 \mathrm{~m}^{2} / \mathrm{g}$ to $168,86 \mathrm{~m}^{2} / \mathrm{g}$ and bentonite pore volume from $0,0065 \mathrm{~cm}^{3} / \mathrm{g}$ to $0,03 \mathrm{~cm}^{3} / \mathrm{g}$. SEM/EDX shows surface morphology particle changes in bentonite, that is for pillared bentonite which $\mathrm{Sn}$ produce particle in the form of granules, while $\mathrm{Cr}$ particles in the form of flake, and EDX give information element content in bentonite to confirm result XRF measurements that shows the $\mathrm{Sn}-\mathrm{Cr}$ metals in pillared bentonite. Measurements with GCMS shows compounds in the liquid of catalytic test results, so as to know the equations with the compounds present in commercial gasoline as reference in this reasearch. From catalysis process, it was found that converted gasoline contained of consists of benzene, toluene, octane, and naphthalene, so that the $\mathrm{Sn}-\mathrm{Cr} / \mathrm{bentonite}$ can be used for ETG catalyst as engine fuel.

\section{ACKNOWLEDGEMENT}

The authors gratefully acknowledge to University of Indonesia for research and study facility, as well as Ministry of Research, Technology \& Higher Education for beasiswa SAINTEK and Research Center for Chemistry, Physics, and Geotechnology - Indonesian Institute of Sciences for research funding and facility.

\section{REFERENCES}

[1] Dan Li, Chunshan Li, Kenzi Suzuki, "Catalytic oxidation of VOCs over Al- and Fe-pillared montmorillonite," Applied Clay Science, vol. 77-78, pp. 56-60, 2013.

[2] Alejandro Perez, Mario Montes, Rafael Molina, Sonia Moreno, "Modified clays as catalysts for the catalytic oxidation of ethanol," Applied Clay Science, vol. 95, pp. 18-24, 2014.

[3] K. Bahranowski, W. Włodarczyk, E. Wisła-Walsh, A. Gaweł, J. Matusik, A. Klimek, B. Gil, A. Michalik-Zym, R. Dula, R.P. Socha, E.M. Serwicka, "[Ti,Zr]-pillared montmorillonite - A new quality with respect to Ti- and Zrpillared clays," Microporous and Mesoporous Materials, vol. 202, pp. 155-164, 2014.

[4] Molina C.B., Casas J.A., Zazo J.A., Rodriguez J.J., "A comparison of Al-Fe and Zr-Fe pillared clays for catalytic wet peroxide oxidation," Chemical Engineering Journal, vol. 118, pp. 29-35, 2006.

[5] Farfan-Torres E.M., Sham E., Grange P., "Pillared Clays: Preparation and Characterization of Zirconium Pillared Montmorillonite," Catalysis Today, vol. 15, pp. 515-526, 1992.

[6] Bartley G.J.J., "Zirconium Pillared Clays," Catalysis Today, vol. 2, pp. 233-241, 1988.

[7] Francine Bertella, Sibele B.C., Pergher, "Pillaring of bentonite clay with Al and Co," Microporous and Mesoporous Materials, vol. 201, pp. 116-123, 2014.

[8] Bulent Caglar, Osman C., Ersin D., Fatih C., Mustafa C., Cihan T., Ahmet T. "Characterization of AlFe-pillared Unye bentonite: A Study of The Surface Acidity and Catalytic Property," Molecular Structure, vol. 1089, pp. 59-65, 2015.

[9] Carla B. Vidal, André B. dos Santos, Ronaldo F. do Nascimento, Teresa J. Bandosz, "Reactive adsorption of pharmaceuticals on tin oxide pillared montmorillonite: Effect of visible light exposure," Chemical Engineering Journal, vol. 259, pp. 865-875, 2014.

[10] Widjaya R.R., Juwono A.L., Rinaldi N., "Bentonite modification with pillarization method using metal stannum," in Proceedings of the 3rd International Symposium on Applied Chemistry, AIP Conference Proceedings, Jakarta, Indonesia, pp. 020010-1-20010-8, 2017.

[11] Guifang Wang, Yuyan Hua, Xin Su, Sridhar Komarneni, Shaojian Ma, Yujue Wang, "Cr(VI) adsorption by montmorillonite nanocomposites," Applied Clay Science, vol. 124-125, pp. 111-118, 2016.

[12] Widjaya R.R., Soegijono B., Rinaldi N., "Characterization of Cr/Bentonit and HZSM-5 Zeolite as Catalysts for Ethanol Conversion to Biogasoline," Makara Journal of Science, vol. 16/1, pp. 65-70, 2012.

[13] Roger Johansson, Sarah L. Hruby, Jeppe Rass-Hansen, Claus H. Christensen, "The Hydrocarbon Pool in Ethanol-toGasoline over HZSM-5 Catalysts," Catal Lett, vol. 127, pp. 1-6, 2008.

[14] Menglin Ding, Shufeng Zuo, Chenze Qi, "Preparation and characterization of novel composite Al/Cr-pillared clays and preliminary investigation for benzene adsorption," Applied Clay Science, vol. 115, pp. 9-16, 2015.

[15] Priambodo N.G., "Pemurnian Minyak Nilam Menggunakan Bentonit Teraktivasi Asam Klorida," Bachelor Thesis. Fakultas Sains dan Teknologi, UIN Sunan Kalijaga, Yogyakarta, Indonesia, 2014. 
[16] Widihati I.A.G., “Adsorpsi anion $\mathrm{Cr}(\mathrm{VI})$ oleh batu pasir teraktivasi asam dan tersalut $\mathrm{Fe}_{2} \mathrm{O}_{3}$," Jurnal Kimia, vol. 2(1), pp. 25-30, 2008.

[17] M.E. Gyftopoulou, M. Millan, A.V. Bridgwater, D. Dugwell, R. Kandiyoti, J.A. Hriljac, "Pillared clays as catalysts for hydrocracking of heavy liquid fuels," Applied Catalysis A, vol. 282, pp. 205-214, 2005.

[18] M. Sowmiya, Aditya Sharma, Sarang Parsodkar, B.G. Mishra, Amit Dubey, "Nanosized sulfated SnO2 dispersed in the micropores of Al-pillared clay as an efficient catalyst for the synthesis of some biologically important molecules," Applied Catalysis A: General, vol. 333, pp. 272-280, 2007.

[19] Is Fatimah, Narsito, Karna Wijaya, "Effect of Aluminium Content in Aluminium Pillared Montmorillonite on Its Surface Acidity Properties," ITB Journal Science, vol. 43, pp. 123-138, 2011.

[20] Yan Gao, Wenjie Li, Huimin Sun, Zaihang Zheng, Xuejun Cui, Hongyan Wang, Fanyu Meng, "A facile in situ pillaring method - the synthesis of Al-pillared montmorillonite,” Applied Clay Science, vol. 88-89, pp. 228-232, 2013.

[21] Nisar Ahmad, Syed Tajammul Hussain, Bakhtiar Muhammad, Nisar Ali, Syed Mustansar Abbas, Zulfiqar Ali, "Zrpillared montmorillonite supported cobalt nanoparticles for Fischer-Tropsch synthesis," Progress in Natural Science : Material International, vol. 23(4), pp. 374-381, 2013.

[22] Takashi Tsuchida, Tetsuya Yoshioka, Shuji Sakuma, Tatsuya Takeguchi, and Wataru Ueda, "Synthesis of Biogasoline from Ethanol over Hydroxyapatite Catalyst,” American Chemical Society, vol. 10, pp. 10.1021, 2008. 